Trop. Anim. Sci. J.

The Addition of Chitosan to GnRH Analog Induces Ovarian Resumption and Improves Conception Rates in Buffaloes

Y. A. Amin \& A. Said

Genetic Identification of Shiga Toxin Encoding Gene from Cases of Multidrug Resistance (MDR) Escherichia coli Isolated from Raw Milk

R. Ansharieta, M. H. Effendi, \& H. Plumeriastuti

Estrous Signs and Progesterone Profile of Ongole Grade Cows Synchronized at Different Ages Fed Different Level of Dietary Crude Protein

R. N. Hayati, Panjono, \& A. Irawan

Characteristics and Potential Production of Frozen Semen of Pasundan Bull

Santoso, Herdis, R. I. Arifiantini, A. Gunawan, \& C. Sumantri

Optimization of Pulsation Rate of the Milking System for the Mammary Gland Remodeling during Involution in Thai Crossbred Holstein Cows

A. Tiantong, K. Sasiwimonrit, S. Saengwong, W. Inyawilert, A. Chaokaur, \& S. E. Chen

Intestinal Morphology, Energy Availability, and Growth Performance of Broilers Treated with the Combination of Probiotic and Inulin

H. Julendra, A. Sofyan, L. Istiqomah, M. F. Karimy, Abinawanto, \& Yasman

Nutritional Evaluation of Sago of Gebang Tree (Corypha utan Lamk) from Different Locations in West Timor - Indonesia for Broilers

C. L. Nalle, Helda, B. Masus, \& J. Malo

Performance, Immune Responses, and Blood Biochemistry of Broiler Chickens Fed with Plant Growth Compound A. Mohseni Gharechopogh, J. Fakhraei, S. A. Hosseini, H. Mansoori Yarahmadi, \& H. Lotfollahian

Performance, Intestinal Histomorphology, and Blood Variables of Broilers Fed Amaranth Grain in Pellet Diet A. H. Alizadeh-Ghamsari, S. A. Hosseini, M. R. Soleymani, \& R. Nahavandi

Administration of Fermented Averrhoa bilimbi L. Fruit Filtrate on Growth, Hematological, Intestinal, and Carcass Indices of Broilers

A. R. Pratama, I. Mareta, T. Yudiarti, H. I. Wahyuni, E. Widiastuti, \& S. Sugiharto

Supplementation of Dietary Nano Zn-Phytogenic on Performance, Antioxidant Activity, and Population of Intestinal Pathogenic Bacteria in Broiler Chickens

C. Hidayat, Sumiati, A. Jayanegara, \& E. Wina

Performance of Male Layer Fed Ration Containing Green Algae (Spirogyra jaoensis) Extract A. R. Ramadhanti, N. O. J. Puspita, C. F. Refalta, H. Kurnianto, \& H. T. S. Saragih

$\beta$-casein Variants and Anti-oxidant Profiles of Milk of Siquijor Native Cattle (Bos taurus indicus L.) as Compared to those of Holstein Friesian x Sahiwal Cattle

G. T. A. Cuevas, A. A. Angeles, F. E. Merca, \& A. J. Salces

Vertical and Horizontal Integration in the Profitability of Malaysian Broiler Firms Y. S. Tey \& P. Arsil

Typology of Dairy Production Systems Based on Management Strategies in Paraná State, Brazil R. C. M. Tramontini, F. I. Bánkuti, M. S. S. Pozza, E. M. Massuda, J. C. Damasceno, A. M. Dias, C. C. B. F. Itavo, L. C. V. Itavo, \& G. T. Santos

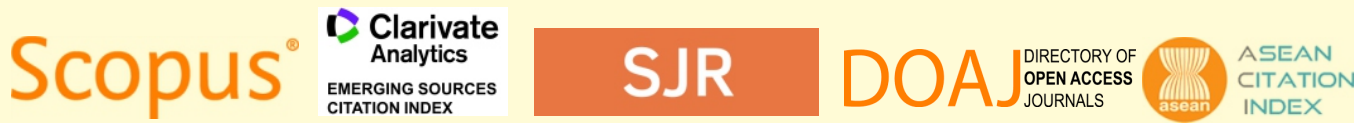

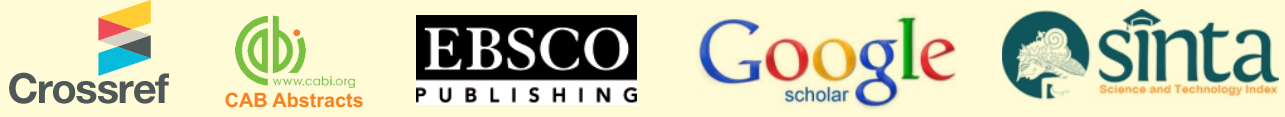




\title{
Tropical Animal Science Journal
}

Accredited by Directorate General of Strengthening for Research and Development, Ministry of Research, Technology and Higher Education of the Republic of Indonesia No: 30/E/KPT/2018

Vol. 44 No. 1, March 2021

PUBLISHER

Faculty of Animal Science, IPB University (Bogor Agricultural University) associated with Animal Scientist's Society of Indonesia

\section{CHIEF EDITOR}

Komang G. Wiryawan

\author{
ASSOCIATE EDITORS \\ Tuti Suryati \\ Sri Suharti \\ Jakaria
}

Abdul Razak Alimon (Malaysia) 2023

Anjas Asmara B. Samsudin (Malaysia)

Anuraga Jayanegara (Indonesia) 2021

Arief Boediono (Indonesia) 2024

Armagan Hayirli (Turkey) 2023

Asep Gunawan (Indonesia) 2023

Budi Santoso (Indonesia) 2021

Burhanudin Sundu (Indonesia) 2023

Cahyo Budiman (Indonesia) 2021

\section{EDITORIAL BOARDS}

Cece Sumantri (Indonesia) 2024

2021 Elizabeth Wina (Indonesia) 2023

Epi Taufik (Indonesia) 2021

Irma Isnafia Arief (Indonesia) 2024

Jong K. Ha (Korea) 2021

Junichi Takahashi (Japan) 2024

Loh Teck Chwen (Malaysia) 2022

Lucia Cyrilla (Indonesia) 2022

Luki Abdullah (Indonesia) 2021
Metha Wanapat (Thailand) 2024

Mulyoto Pangestu (Australia) 2022

Myunggi Baik (Korea) 2021

Nahrowi (Indonesia) 2024

Rita Mutia (Indonesia) 2022

Sri Mulatsih (Indonesia) 2021

Wasmen Manalu (Indonesia) 2024

\section{TECHNICAL EDITORS \\ Irma Nuranthy Purnama \\ Yuni Cahya Endrawati}

\section{SCOPE OF JOURNAL}

Tropical Animal Science Journal receives original manuscripts encompass a broad range of research topics in tropical animal sciences: breeding and genetics, reproduction and physiology, nutrition, feed sciences, agrostology, animal products, biotechnology, behaviour, welfare, health and veterinary, livestock farming system, socio-economic, animal waste management, and policy.

Authors have to prepare the manuscripts according to Tropical Animal Science Journal's guidelines. Manuscript and statement of originality and copyright release form (Form A) should be submitted via online submission through journal website: http://journal.ipb. ac.id/index.php/tasj.

\section{ABOUT JOURNAL}

Tropical Animal Scince Journal (Trop. Anim. Sci. J.) previously Media Peternakan is a scientific journal covering broad aspects of tropical animal sciences. Started from 2018, the title is changed from Media Peternakan in order to develop and expand the distribution as well as increase the visibility of the journal. The journal is published FOUR times a year in March, June, September, and December by Faculty of Animal Science, IPB University (Bogor Agricultural University), associated with Animal Scientist's Society of Indonesia. Tropical Animal Scince Journal is a peer reviewed journal that has been indexed and abstracted in Elsevier products (Scopus, Reaxys), Clarivate Analytics product (Emerging Sources Citation Index), Scimago Journal Rank, ASEAN Citation Index, DOAJ, DimensionsDigital Science, CABI, EBSCO, Science and Technology Index (SINTA), Google Scholar, and other scientific databases. The journal also uses Similarity Check to prevent any suspected plagiarism in the manuscripts.

\section{SECRETARIAT OF TROPICAL ANIMAL SCIENCE JOURNAL}

Faculty of Animal Science Building, IPB University (Bogor Agricultural University)

Jalan Agatis, Kampus IPB Dramaga, Bogor 16680, Indonesia

Phone/Fax: +62-251-8421692

e-mail: mediapeternakan@apps.ipb.ac.id

website: http://journal.ipb.ac.id/index.php/tasj

Subscription Rate (Not including shipping and handling):

IDR 100.000/ edition and IDR 350.000/ year (Indonesian subscribers); 50 US\$ (Foreign subscribers)

Bank account: Bank Rakyat Indonesia KCP KAMPUS IPB No. 0595-01-005208-53-3, o.b. Media Peternakan, SWIFT CODE: BRINIDJA 


\title{
Tropical Animal Science Lounal
}

Accredited by Directorate General of Strengthening for Research and Development, Ministry of Research, Technology and Higher Education of the Republic of Indonesia

No: 30/E/KPT/2018

\begin{abstract}
HISTORY
Tropical Animal Science Journal (Trop. Anim. Sci. J.) (p-ISSN 2615-787X and e-ISSN 2615-790X) previously Media Peternakan (published from 1967-2017 with p-ISSN 0126-0476 and e-ISSN 2087-4634) is a scientific journal covering broad aspects of tropical animal sciences. Started from 2018, the title is changed from Media Peternakan in order to develop and expand the distribution as well as increase the visibility of the journal. The journal is published FOUR times a year in March, June, September, and December started from the year 2020 by Faculty of Animal Science, IPB University (Bogor Agricultural University), associated with Animal Scientist's Society of Indonesia.

The first edition with the new title was published in April 2018 edition (Vol 41 No 1 2018), while the previous edition (up to 2017 edition) still use Media Peternakan as the title. The online version of Tropical Animal Scince Journal could be accessed in the new website (http://journal.ipb.ac.id/index.php/tasj) and the previous editions are available in the old website (http://medpet.journal.ipb.ac.id/).

Tropical Animal Science Journal has been indexed and abstracted in Elsevier products (Scopus, Reaxys), Clarivate Analytics products (Emerging Sources Citation Index), Scimago Journal Rank, ASEAN Citation Index, DOAJ, Dimensions-Digital Science, CABI, EBSCO, Science and Technology Index (SINTA), Google Scholar, and other scientific databases. The journal also uses Similarity Check to prevent any suspected plagiarism in the manuscripts.
\end{abstract}




\title{
Tropical Animal Science
}

\author{
gacrual
}

Accredited by Directorate General of Strengthening for Research and Development,

Ministry of Research, Technology and Higher Education of the Republic of Indonesia

No: 30/E/KPT/2018

\section{LIST OF CONTENT}

The Addition of Chitosan to GnRH Analog Induces Ovarian Resumption and Improves Conception Rates in

Buffaloes

Y. A. Amin \& A. Said

Genetic Identification of Shiga Toxin Encoding Gene from Cases of Multidrug Resistance (MDR) Escherichia coli

Isolated from Raw Milk

R. Ansharieta, M. H. Effendi, \& H. Plumeriastuti

Estrous Signs and Progesterone Profile of Ongole Grade Cows Synchronized at Different Ages Fed Different Level

of Dietary Crude Protein

R. N. Hayati, Panjono, \& A. Irawan

Characteristics and Potential Production of Frozen Semen of Pasundan Bull

Santoso, Herdis, R. I. Arifiantini, A. Gunawan, \& C. Sumantri

Optimization of Pulsation Rate of the Milking System for the Mammary Gland Remodeling during Involution in Thai Crossbred Holstein Cows

A. Tiantong, K. Sasiwimonrit, S. Saengwong, W. Inyawilert, A. Chaokaur, \& S. E. Chen

Intestinal Morphology, Energy Availability, and Growth Performance of Broilers Treated with the Combination of Probiotic and Inulin

H. Julendra, A. Sofyan, L. Istiqomah, M. F. Karimy, Abinawanto, \& Yasman

Nutritional Evaluation of Sago of Gebang Tree (Corypha utan Lamk) from Different Locations in West Timor Indonesia for Broilers

C. L. Nalle, Helda, B. Masus, \& J. Malo

Performance, Immune Responses, and Blood Biochemistry of Broiler Chickens Fed with Plant Growth Compound A. Mohseni Gharechopogh, J. Fakhraei, S. A. Hosseini, H. Mansoori Yarahmadi, \& H. Lotfollahian

Performance, Intestinal Histomorphology, and Blood Variables of Broilers Fed Amaranth Grain in Pellet Diet A. H. Alizadeh-Ghamsari, S. A. Hosseini, M. R. Soleymani, \& R. Nahavandi

Administration of Fermented Averrhoa bilimbi L. Fruit Filtrate on Growth, Hematological, Intestinal, and Carcass Indices of Broilers

A. R. Pratama, I. Mareta, T. Yudiarti, H. I. Wahyuni, E. Widiastuti, \& S. Sugiharto

Supplementation of Dietary Nano Zn-Phytogenic on Performance, Antioxidant Activity, and Population of Intestinal Pathogenic Bacteria in Broiler Chickens

C. Hidayat, Sumiati, A. Jayanegara, \& E. Wina

Performance of Male Layer Fed Ration Containing Green Algae (Spirogyra jaoensis) Extract

A. R. Ramadhanti, N. O. J. Puspita, C. F. Refalta, H. Kurnianto, \& H. T. S. Saragih

$\beta$-casein Variants and Anti-oxidant Profiles of Milk of Siquijor Native Cattle (Bos taurus indicus L.) as Compared to those of Holstein Friesian $x$ Sahiwal Cattle

G. T. A. Cuevas, A. A. Angeles, F. E. Merca, \& A. J. Salces

Vertical and Horizontal Integration in the Profitability of Malaysian Broiler Firms

Y. S. Tey \& P. Arsil

Typology of Dairy Production Systems Based on Management Strategies in Paraná State, Brazil

R. C. M. Tramontini, F. I. Bánkuti, M. S. S. Pozza, E. M. Massuda, J. C. Damasceno, A. M. Dias, C. C. B. F. Ítavo, L. C. V. Ítavo, \& G. T. Santos 